\title{
KEIKUTSERTAAN INDONESIA PADA MASYARAKA EKONOMI ASEAN DAN IMPLIKASINYA TERHADAP PENGATURAN PENGGUNAAN TENAGA KERJA ASING
}

\author{
Inda Rahadiyan ${ }^{1}$ \\ Karina Amanda Savira²
}

\begin{abstract}
Abstrak Permasalahan yang dikaji dalam penelitian ini adalah bagaimana implikasi keikutsertaan Indonesia pada Masyarakat Ekonomi ASEAN (MEA) terhadap pengaturan penggunaan Tenaga Kerja Asing (TKA). Penelitian dilakukan dengan menggunakan metode studi kepustakaan (library research). Hasil penelitian menunjukkan bahwa keikutsertaan Indonesia pada MEA menimbulkan implikasi terhadap pengaturan TKA, diantara yakni pengaturan mengenai penggunaan TKA.
\end{abstract}

Kata kunci: Masyarakat Ekonomi ASEAN, Tenaga Kerja Asing.

\section{PENDAHULUAN}

Komitmen para pemimpin negara Asia Tenggara dalam rangka membentuk masyarakat ASEAN (ASEAN Community) sebagaimana tercantum di dalam Visi ASEAN $2020^{3}$ telah memasuki tahapan baru pasca tercapainya kesepakatan pembentukan Masyarakat Ekonomi ASEAN (MEA) pada pertemuan Bali Concord II. ${ }^{4}$ Berbagai pertemuan terkait pembentukan MEA terus dilakukan secara berkesinambungan oleh para pemimpin negara ASEAN. Salah satu hasil kesepakatan penting yang dicapai adalah mengenai percepatan rencana pembentukan MEA yang semula diagendakan pada tahun 2020 kemudian dipercepat sehingga pembentukan MEA disepakati akan dilaksanakan pada tahun $2015 .^{5}$

Sebagai suatu bentuk liberalisasi ekonomi regional, MEA memiliki

\footnotetext{
1 Penulis menyelesaikan pendidikan Strata Satu dan Strata Dua pada Fakultas Hukum Universitas Gadjah Mada. Kini penulis adalah Dosen Tetap pada Fakultas Hukum Universitas Islam Indonesia dengan bidang kekhususan hukum perdata-bisnis

${ }^{2}$ Mahasiswa aktif pada Fakultas Hukum Universitas Islam Indonesia dengan program kekhususan hukum perdatabisnis

3 Mengenai ini baca: ASEAN Vision 2020, http://www.aseansec.org/1814.htm

Mengenai ini baca: Bali Concord $\mathrm{II}_{2}$ http://www.aseansec.org/15159.htm

${ }^{5}$ Kesepakatan ini dicapai pada KTT ASEAN ke-12 bulan Januari tahun 2007.
}

karakteristik utama yang meliputi; (1) pasar tunggal dan basis produksi tunggal, (2) kawasan ekonomi yang berdaya saing tinggi, (3) kawasan dengan pembangunan ekonomi yang merata, serta (4) kawasan yang terintegrasi penuh dengan ekonomi global. ${ }^{6}$ Berdasarkan pada karakteristik yang demikian maka sistem perekonomian kawasan Asia Tenggara akan benar-benar menyatu dengan sistem perekonomian global. Integrasi sistem perekonomian dalam konteks demikian tentu memiliki implikasi dan keterkaitan dengan berbagai aspek kehidupan. Salah satu aspek penting yang terkait dalam konteks ini adalah aspek ketenagakerjaan.

Hal demikian dapat dipahami mengingat salah satu elemen utama kesepakatan MEA adalah terbentuknya aliran bebas tenaga kerja terdidik (skilled labor). ${ }^{7}$ Aliran bebas tenaga kerja ini pada tataran selanjutnya akan berimplikasi pada kebijakan setiap negara anggota dalam menciptakan regulasi ketenagakerjaan khususnya pengaturan penggunaan Tenaga Kerja Asing (TKA).

\footnotetext{
6 ASEAN Economic Community Blueprint, http:www.//asean.org

${ }^{7}$ Baca: ASEAN Economic Community Blueprint, http:www.//asean.org

Volume 2 Nomor 2, Juni $2017 \mid 9$
} 
Pengaturan terhadap TKA ${ }^{8}$ menjadi salah satu isu krusial mengingat semangat hukum ketenagakerjaan di Indonesia sejatinya ditujukan bagi terwujudnya jaminan kesempatan bekerja ${ }^{9}$ bagi seluruh Warga Negara Idonesia. ${ }^{10}$ Oleh karena itu, pengkajian/analisis mengenai implikasi keikutsertaan Indonesia pada MEA terhadap pengaturan penggunaan TKA menjadi suatu hal yang penting untuk dilakukan.

\section{RUMUSAN MASALAH}

Penelitian ini dilakukan dalam rangka menjawab sebuah rumusan masalah yakni bagaimana implikasi keikutsertaan Indonesia pada Masyarakat Ekonomi ASEAN terhadap pengaturan penggunaan Tenaga Kerja Asing?

\section{TUJUAN PENELITIAN}

Penelitian ini bertujuan untuk mengkaji pengaruh keikutsertaan Indonesia pada MEA terhadap pengaturan penggunaan tenaga kerja asing.

\section{METODE PENELITIAN}

Metode yang digunakan untuk menjawab rumusan masalah dalam penelitian ini adalah metode penelitian kepustakaan (library research). Penelitian kepustakaan dilakukan dengan mengumpulkan, mempelajari serta menganalisis berbagai sumber pustaka yang relevan. Data hasil penelitian kemudian disajikan secara kualitatif berdasarkan relevansinya terhadap rumusan masalah. ${ }^{11}$

\footnotetext{
${ }^{8}$ Berdasarkan Pasal 1 angka 13 Undang-Undang Nomor 13 Tahun 2003 tentang Ketenagakerjaan, yang dimaksud dengan Tenaga Kerja Asing (TKA) adalah warga negara asing pemegang visa dengan maksud untuk bekerja di wilayah Indonesia.

9 Mengenai ini baca Undang-Undang Dasar Negara Republik Indonesia Tahun 1945

${ }^{10}$ Uraian lebih lanjut mengenai hal ini, baca: ${ }^{10}$ May Yanti Budiarti, Perizinan Penggunaaan Tenaga Kerja Asing Dengan Berlakunya Masyarakat Ekonomi ASEAN, Tesis, Magister IImu Hukum, Universitas Negeri Lampung, 2016, diakses dari www.digilib.unila.ac.id pada tanggal 23 Januari 2017 pukul 11:51 WIB.

${ }^{11}$ Johny Ibrahim, Teori dan Metodologi Penelitian Normatif, 2006, Bayumedia Publishing, Malang, hlm. 63.
}

5. HASIL PENELITIAN DAN PEMBAHASAN

5.1 Masyarakat Ekonomi ASEAN Sebagai Bentuk Liberalisasi Ekonomi Regional

'Interdependence" may be overused but it accurately describes our world today. Economic forces flow with great rapidity from one country to the next. Despite all the talk about sovereignty and independence, in the fact these concepts can mislead and irrelevant when applied to the today's world economy. ${ }^{12}$ Kutipan ini memberikan gambaran jelas mengenai kondisi perekonomian dunia dewasa ini yang menunjukkan adanya ketergantungan antar negara terlebih sejak muncul dan berkembangnya arus globalisasi. Saling ketergantungan (interdependensi) antar negara pada tataran selanjutnya telah mendorong terjadinya penyatuan (integrasi) ekonomi baik dalam skala global ${ }^{13}$ maupun dalam skala regional. ${ }^{14}$

$$
\text { Integrasi perekonomian }
$$

ditandai dengan lahirnya berbagai kerjasama ekonomi antar negara. Secara historis terbentuknya World Trade Organization (WTO) didahului oleh terbentuknya blokblok ekonomi regional seperti Masyarakat Ekonomi Eropa (European Union), NAFTA, AFTA serta APEC. Dengan demikian, tidak ada kontradiksi antara regionalisasi dengan globalisasi ekonomi. Sebaliknya, integrasi ekonomi global telah mendorong terciptanya integrasi ekonomi regional termasuk di dalamya

\footnotetext{
12 John H. Jackson, William J. Davey and Alan O. Sykes. Legal Problems of International Economic Relations. 2002. West Group. ST Paull Minn., hlm.1.

${ }^{13}$ Integrasi ekonomi dalam skala global terutama ditandai dengan lahirnya World Trade Organization (WTO).

14 Integrasi ekonomi dalam skala regional ditandai dengan kemunculan berbagai kerjasama ekonomi regional seperti NAFTA, AFTA, APEC. 


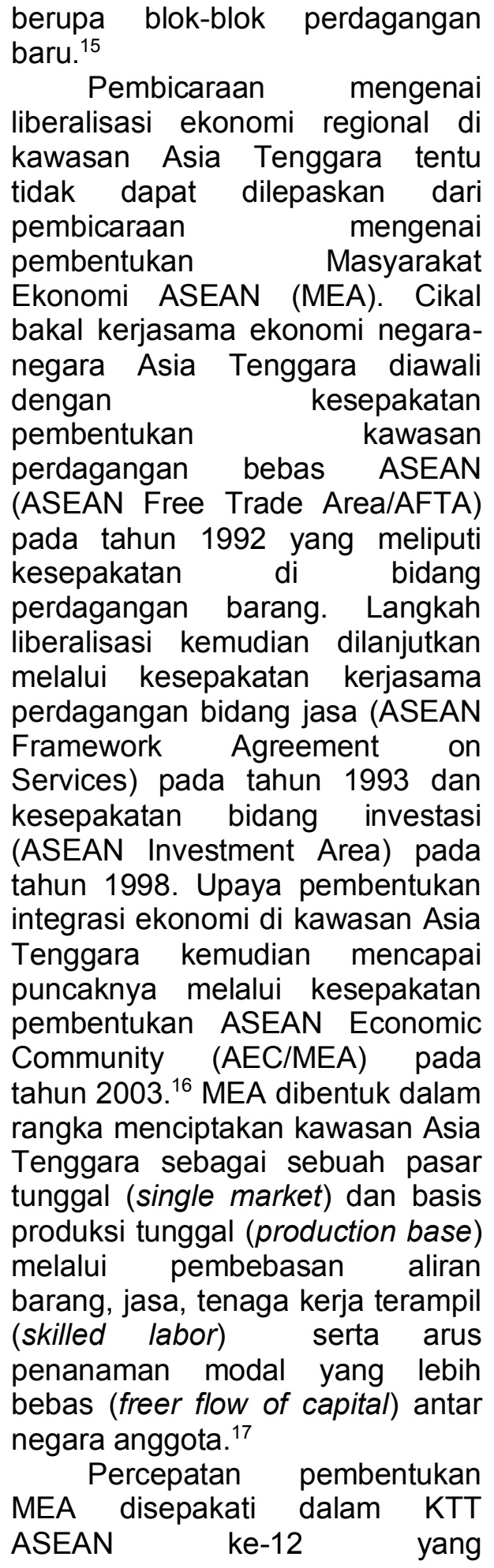

${ }^{15}$ Bary Hufbauer, "International Trade Organization and Economies in Transition: A Glimpse of The Twenty-First Century", Law and Policy in International Business, Vol.29, 1995, hlm.108

${ }^{16}$ Chia, S.Y., 2013, "The ASEAN Economic Community: Progress, Challenges and Prospects", ADBI Working Paper 440. Tokyo: Asian Development Bank Institute, hlm. 1, http://www.adbi.org, diakses pada tanggal 03 Februari 2015 pukul 14.40 WIB.

${ }^{17}$ ASEAN Economic Community Blueprint, Loc.Cit. diselenggarakan pada bulan Januari $2007 \quad$ melalui penandatanganan "Declaration on the Acceleration of the Establishment of an ASEAN Community by 2015". Sebagai tindak lanjut atas kesepakatan tersebut, para Menteri Ekonomi ASEAN menginstruksikan kepada Sekretariat ASEAN untuk menyusun sebuah Cetak Biru ASEAN Economic Community ${ }^{18}$ yang memuat empat pilar utama:

(1) ASEAN sebagai pasar tunggal dan basis produksi tunggal yang didukung dengan elemen aliran bebas barang, jasa, tenaga kerja

terdidik dan aliran modal yang lebih bebas;

(2) ASEAN sebagai kawasan yang berdaya saing tinggi di bidang ekonomi dengan elemen peraturan kompetisi, perlindungan

konsumen, hak atas kekayaan intelektual, pengembangan

infrastruktur, perpajakan dan e-commerce;

(3) ASEAN sebagai kawasan pengembangan ekonomi yang bersifat merata dengan elemen pengembangan usaha kecil dan menengah serta prakarsa integrasi ASEAN untuk negara-negara Kamboja, Laos dan Vietnam;

(4) ASEAN sebagai kawasan yang terintegrasi penuh dengan

perekonomian global.

Aliran bebas tenaga kerja terdidik (skilled labor $)^{19}$

18 Dian Triansyah Djani, "ASEAN Selayang Pandang", Direktur Jendral Kerjasama ASEAN, Jakarta, hlm. 33.

${ }^{19}$ Berdasarkan kepustakaan bisnis, skilled labour/skilled worker didefinisikan sebagai: "An individual that is 
merupakan elemen utama dalam kesepakatan MEA. ${ }^{20} \mathrm{Hal}$ ini berarti bahwa era liberaliasi ekonomi regional dalam konteks MEA akan ditandai dengan aliran bebas tenaga kerja terdidik di antara negara anggota.

\subsection{Keikutsertaan Indonesia Pada Masyarakat Ekonomi ASEAN dan Implikasinya Terhadap Pengaturan Penggunaan TKA}

Pembebasan aliran tenaga kerja terdidikmenuntut kesiapan Pemerintah Indonesia untuk mengambil langkah-langkah strategis guna menghadapi era liberalisasi tenaga kerja terampil regional ini.

Sesuai dengan fungsi dan kewenangannya, Pemerintah telah melakukan berbagai upaya dalam rangka menghadapai era aliran bebas TKA dalam konteks MEA. ${ }^{21}$ Setidaknya terdapat empat langkah strategis yang telah dilakukan oleh Pemerintah melalui Kemenakertrans dalam rangka pengaturan TKA, yakni: ${ }^{22}$

(1) Memperketat pengaturan terkait tenaga kerja asing (TKA)

Pengetatan terhadap aturan penggunaan TKA dilakukan dalam rangka melindungi Tenaga Kerja Indonesia (TKI). Langkah memperketat aturan penggunaan TKA

knowledgeable about a specific skill or trade. Definisi diakses dari Business Dictionary, www.businessdictionary.com. Pada tanggal 23 Januari 2017 pada pukul 13.40 WIB.

${ }^{20}$ Baca: ASEAN Economic Community Blue Print, loc.cit. ${ }^{21}$ Anonim,

http://www.hukumonline.com/berita/baca/lt5464d0751336 8/jelang-mea--kemenakertrans-perketat-aturan-tenagakerja-asingdiakses pada hari Sabtu tanggal 14 Februari 2015 jam 13.19 WIB.

${ }^{22}$ Rencana Kemenakertrans untuk memperketat aturan aturan tenaga kerja asing tersebut sebagaimana diungkapkan oleh Sekretaris Jenderal Kemenakertrans Bapak Abdul Wahab Bangkona dalam acara Forum Komunikasi Bakohumas Kemenakertrans pada hari Kamis tanggal 13 November 2014. Berkaitan dengan hal ini baca: Anonim, http://www.hukumonline.com/berita/baca/lt5464d0751336 8/jelang-mea--kemenakertrans-perketat-aturan-tenagakerja-asing diwujudkan

dengan

menerbitkan

peraturan-

peraturan

menyangkut

batasan jabatan-jabatan

yang dapat diduduki oleh

TKA sehingga TKI akan tetap dapat terserap dengan baik.

(2) Melakukan perbaikan terhadap sistem pelayanan publik terkait perizinan dan pendataan tenaga kerja asing secara online ${ }^{23}$

Melalui sistem pelayanan secara online, masyarakat dapat melakukan konsultasi terkait penggunaan tenaga kerja asing dengan memanfaatkan fitur sarana teknologi informasi berbasis internet. Selain itu guna memperbaiki sarana dan prasarana pelayanan penggunaan TKA, Kemenakertrans juga telah memperbanyak loket pelayananinformasi terkait penggunaan tenaga kerja asing.

(3) Kewajiban

bagi perusahaan mempekerjakan kerja asing untuk mencermati undangundang ketenagakerjaan ${ }^{24}$ Perusahaan yang mempekerjakan TKA harusmencermati kewajibankewajibantertentu berkaitan dengan penggunaan TKA sebagaimana diamanatkan oleh peraturan perundang-

\footnotetext{
${ }^{23} \mathrm{Hal}$ tersebut sebagaimana diungkapkan oleh Bapak Herry Sudarmanto selaku Direktur Pengendalian Penggunaan Tenaga Kerja Asing Kemenakertrans dalam acara Forum Komunikasi Bakohumas Kemenakertrans pada hari Kamis tanggal 13 November 2014. Berkaitan dengan hal ini baca :"Jelang MEA Kemenakertrans Perketat Aturan Tenaga Kerja Asing", http://www.hukumonline.com/berita/baca/lt5464d0751336 8/jelang-mea--kemenakertrans-perketat-aturan-tenagakerja-asing

${ }^{24} \mathrm{Hal}$ tersebut sebagaimana diungkapkan oleh Sekretaris Jenderal Kemenakertrans Bapak Abdul Wahab Bangkona, loc.cit. 
undangan. Kewajibankewajiban dimaksud antara lain: Pertama, penunjukan tenaga kerja Indonesia sebagai pendamping dari tenaga kerja asing yang bekerja pada perusahaan yang bersangkutan. ${ }^{25}$ Kedua, ketaatan terhadap ketentuan mengenai jabatan dan standar kompensasi yang berlaku $^{26}$. Ketiga, pihak yang mempekerjakan TKA berkewajiban memulangkan TKA ke negara asalnya setelah masa perjanjian kerja berakhir. ${ }^{27}$

(4) Memperketat pengawasan dan penegakan hukum ${ }^{28}$

Pengawasan terhadap penggunaan TKA dilakukan mulai dari tingkat pusat hingga daerah melalui kerja sama dengan pihak imigrasi, kepolisian serta instansi terkait lainnya. Selain memperketat pengawasan, upaya lain yang terus dilakukan adalah mengenau optimalisasi penegakan hukum. Upaya-upaya tersebut dimaksudkan dalam rangka membenahi sistem penggunaan tenaga TKA dan

\footnotetext{
${ }^{25}$ Kewajiban untuk melakukan penunjukan tenaga kerja Indonesia sebagai pendamping tenaga kerja asing diatur di dalam Pasal 45 Undang-Undang Nomor 13 Tahun 2003 Tentang Ketenagakerjaan. Tujuan dari penunjukan tenaga kerja pendamping tersebut adalah untuk alih teknologi dan alih keahlian. Pihak yang mempekerjakan tenaga kerja asing wajib untuk melaksanakan pendidikan dan pelatihan kerja yang sesuai dengan kualifikasi jabatan yang diduduki oleh tenaga kerja asing. Pendidikan dan pelatihan tersebut ditujukan bagi tenaga kerja Indonesia yang berperan sebagaipendamping tenaga kerja asing. Pendampingan oleh tenaga kerja Indonesia ini dimaksudkan untuk transfer ilmu dan teknologi dari tenaga kerja asing ke tenaga kerja Indonesia. Transfer ilmu dan teknologi ini dimaksudkan agar tenaga kerja Indonesia memiliki kemampuan untuk menduduki jabatan yang sebelumnya diduduki oleh tenaga kerja asing. Tenaga kerja Indonesia yang menjadi pendamping tenaga kerja asing memiliki peran yang sangat penting yaitu mamastikan bahwa transfer ilmu dan teknologi dari tenaga kerja asing dapat berjalan dengan baik.

26 Pasal 44 Undang-Undang Nomor 13 Tahun 2003 tentang Ketenagakerjaan.

${ }^{27}$ Pasal 48 Undang-Undang Nomor 13 Tahun 2003 tentang Ketenagakerjaan.

${ }^{28}$ /bid.
}

\author{
meningkatkan daya saing \\ TKI dalam menghadapi \\ persaingan dunia kerja.
}

Khusus berkaitan dengan penggunaan TKA, hanya beberapa pihak saja yang diperbolehkan oleh peraturan perundangundangan untuk mempekerjakan TKA, antara lain : ${ }^{29}$ instansi pemerintah, badan-badan internasional, perwakilan negara asing, kantor perwakilan dagang asing, kantor perwakilan perusahaan asing, kantor perwakilan berita asing, perusahaan swasta asing, badan hukum yang didirikan berdasarkan hukum Indonesia atau badan usaha asing yang terdaftar di instansi berwenang di Indonesia, lembaga sosial, keagamaan, pendidikan dan kebudayaan; usaha jasa impresariat. ${ }^{30}$ Pihak yang mempekerjakan TKA harus memiliki izin tertulis dari Menteri Tenaga Kerjadan Transmigrasi 31 serta harus memiliki Rencana Penggunaan Tenaga Kerja Asing. 32

Pada level teknis, terdapat pula beberapa keputusan menteri yang mengatur mengenai jabatanjabatan tertentu yang dapat diduduki TKA. Beberapa diantara keputusan-keputusan tersebut, yakni:

(1) Keputusan Menteri Tenaga

\begin{tabular}{lcrr} 
Kerja & dan & \multicolumn{2}{c}{ Transmigrasi } \\
Nomor & 40 & Tahun & 2012 \\
tentang & \multicolumn{2}{c}{ Jabatan-Jabatan } \\
Tertentu & \multicolumn{2}{c}{ Yang } & Dilarang \\
Diduduki & \multicolumn{2}{c}{ Tenaga } & Kerja \\
Asing. & &
\end{tabular}

${ }^{29}$ Pasal 3 Peraturan Menteri Tenaga Kerja dan
Transmigrasi Republik Indonesia Nomor 12 Tahun 2013
tentang Tata Cara Penggunaan Tenaga Kerja Asing.
${ }^{30}$ Usaha jasa impresariat adalah kegiatan pengurusan
penyelenggaraan hiburan di Indonesia, baik yang
mendatangkan maupun memulangkan tenaga kerja asing
di bidang seni dan olahraga yang bersifat sementara.
${ }^{31}$ Pasal 42 ayat (1) Undang-Undang Nomor 13 Tahun
2003 tentang Ketenagakerjaan.
${ }^{32}$ Pasal 43 ayat (1) Undang-Undang Nomor 13 Tahun
2003 tentang Ketenagakerjaan.
$\begin{array}{llllll}\text { u e } 2 \text { N o m o r 2, J u n i } 2017 & 13\end{array}$ 
(2) Keputusan Menteri Tenaga Kerja dan Transmigrasi Nomor 354 Tahun 2013 tentang Jabatan Yang Dapat Diduduki Oleh Tenaga Kerja Asing Pada Kategori Industri Pengolahan Golongan Pokok Industri Minuman.

(3) Keputusan Menteri Tenaga Kerja dan Transmigrasi Nomor 355 Tahun 2013 tentang Jabatan Yang Dapat Diduduki Oleh Tenaga Kerja Asing Pada Kategori Pengadaan air, Pengelolaan Sampah dan Daur Ulang, Pembuangan dan Pembersihan Limbah dan Sampah Golongan Pokok Pengelolaan Limbah.

(4) Keputusan Menteri Tenaga Kerja dan Transmigrasi Nomor 356 Tahun 2013 tentang Jabatan Yang dapat Diduduki Oleh Tenaga Kerja Asing Pada Kategori Industri Pengolahan Golongan Pokok Industri Tekstil.

(5) Keputusan Menteri Tenaga Kerja dan Transmigrasi Nomor 357 Tahun 2013 tentang Jabatan Yang Dapat Diduduki Oleh Tenaga Kerja Asing Pada Kategori Industri Pengolahan Golongan Pokok Industri Pakaian Jadi.

(6) Keputusan Menteri Tenaga Kerja dan Transmigrasi Nomor 358 Tahun 2013 tentang Jabatan Yang Dapat Diduduki Oleh Tenaga Kerja Asing Pada Kategori Industri Pengolahan Golongan Pokok Industri Makanan.

(7) Keputusan Menteri Tenaga Kerja dan Transmigrasi Nomor 359 Tahun 2013 tentang Jabatan Yang Dapat Diduduki Oleh Tenaga Kerja Asing Pada Kategori Industri Pengolahan Golongan Pokok Industri Barang Logam Bukan Mesin Dan Peralatannya.
(8) Keputusan Menteri Tenaga Kerja dan Transmigrasi Nomor 708 Tahun 2012 tentang Jabatan Yang Dapat Diduduki Oleh Tenaga Kerja Asing Pada Kategori Kesenian, Hiburan, Dan Rekreasi Golongan Pokok Kegiatan Hiburan, Kesenian Dan Kreativitas Dan Golongan Pokok Olahraga dan Rekreasi Lainnya.

Dengan pengaturan yang demikian maka TKA yang akan bekerja di Indonesia hanya diperbolehkan untuk menduduki jabatan-jabatan tertentu. Ketentuan mengenai jabatanjabatan tertentu yang dapat diduduki oleh TKA wajib ditaati oleh pihak yang mempekerjakan TKA.

\section{PENUTUP}

Pembebasan aliran tenaga kerja terdidik (free flow of skilled labor) sebagaimana kesepakatan MEAmenuntut kesiapan Pemerintah Indonesia untuk mengambil langkah-langkah strategis guna menghadapi era liberalisasi tenaga kerja ini. Pemerintah Indonesia melalui Kementrian Tenaga Kerja dan Transmigrasi telah melakukan berbagai upaya pengaturan terhadap TKA.Pengaturan terhadap TKA dimaksud, antara lain adalah pengaturan mengenai batasan penggunaan TKA dan aturan mengenai jabatan-jabatan tertentu yang dapat diduduki oleh TKA. Melalui berbagai pengaturan yang telah dilakukan, diharapkan keikutsertaan Indonesia pada MEA tidak menimbulkan dampak negatif terutama bagi TKI dalam hal memperoleh jaminan kesempatan bekerja.

\section{DAFTAR PUSTAKA}

\section{Buku}

Dian Triansyah Djani, ASEAN Selayang Pandang, Direktur Jenderal Kerjasama ASEAN, Jakarta, hlm. 33. 
John H. Jackson, William J. Davey and Alan O. Sykes. Legal Problems of International Economic Relations. 2002. West Group. ST Paull Minn., hlm.1.

Johny Ibrahim, Teori dan Metodologi Penelitian Normatif, 2006, Bayumedia Publishing, Malang, hlm. 63.

\section{Jurnal}

Bary Hufbauer, International Trade Organization and Economies in Transition: A Glimpse of the Twenty-First Century, Law and Policy in International Business, Vol.29, 1995.

\section{Hasil Penelitian}

May Yanti Budiarti, Perizinan Penggunaaan Tenaga Kerja Asing Dengan Berlakunya Masyarakat Ekonomi ASEAN, Tesis, Magister IImu Hukum, Universitas Negeri Lampung, 2016.

\section{Peraturan Perundang-Undangan dan Keputusan Menteri}

Undang-Undang Dasar Negara Kesatuan Republik Indonesia Tahun 1945

Undang-Undang Republik Indonesia Nomor 13 Tahun 2003 tentang Ketenagakerjaan

Peraturan Menteri Tenaga Kerja dan Transmigrasi Republik Indonesia Nomor 12 Tahun 2013 tentang Tata Cara Penggunaan Tenaga Kerja Asing

Keputusan Menteri Tenaga Kerja dan Transmigrasi Nomor 354 Tahun 2013 Tentang Jabatan Yang Dapat Diduduki Oleh Tenaga Kerja Asing Pada Kategori Industri Pengolahan Golongan Pokok Industri Minuman

Keputusan Menteri Tenaga Kerja dan Transmigrasi Nomor 355 Tahun 2013 Tentang Jabatan Yang Dapat Diduduki
Oleh Tenaga Kerja Asing Pada Kategori Pengadaan air, Pengelolaan Sampah dan Daur Ulang, Pembuangan dan Pembersihan Limbah dan Sampah Golongan Pokok Pengelolaan Limbah

Keputusan Menteri Tenaga Kerja dan Transmigrasi Nomor 356 Tahun 2013 Tentang Jabatan Yang dapat Diduduki Oleh Tenaga Kerja Asing Pada Kategori Industri Pengolahan Golongan Pokok Industri Tekstil

Keputusan Menteri Tenaga Kerja dan Transmigrasi Nomor 357 Tahun 2013 Tentang Jabatan Yang Dapat Diduduki Oleh Tenaga Kerja Asing Pada Kategori Industri Pengolahan Golongan Pokok Industri Pakaian Jadi

Keputusan Menteri Tenaga Kerja dan Transmigrasi Nomor 358 Tahun 2013 Tentang Jabatan Yang Dapat Diduduki Oleh Tenaga Kerja Asing Pada Kategori Industri Pengolahan Golongan Pokok Industri Makanan

Keputusan Menteri Tenaga Kerja dan Transmigrasi Nomor 359 Tahun 2013 Tentang Jabatan Yang Dapat Diduduki Oleh Tenaga Kerja Asing Pada Kategori Industri Pengolahan Golongan Pokok Industri Barang Logam Bukan Mesin Dan Peralatannya

Keputusan Menteri Tenaga Kerja dan Transmigrasi Nomor 40 Tahun 2012 Tentang Jabatan-Jabatan Tertentu Yang Dilarang Diduduki Tenaga Kerja Asing

Keputusan Menteri Tenaga Kerja dan Transmigrasi Nomor 708 Tahun 2012 Tentang Jabatan Yang Dapat Diduduki Oleh Tenaga Kerja Asing Pada Kategori Kesenian, Hiburan, Dan Rekreasi Golongan Pokok Kegiatan Hiburan, Kesenian Dan Kreativitas Dan Golongan Pokok Olahraga dan Rekreasi Lainnya 


\section{Data Elektronik}

Anonim, Kemenakertrans Perketat Aturan Tenaga Kerja www.hukumonline.com.

ASEAN Economic Community Blueprint, http:www.//asean.org

ASEAN Vision

http://www.aseansec.org
Bali Concord II, http://www.aseansec.org

Business

Dictionary,

www.businessdictionary.com.

Chia, S.Y., 2013, The ASEAN Economic Community: Progress, Challenges and Prospects", ADBI Working Paper 440. Tokyo: Asian Development Bank Institute, http://www.adbi.org 